\title{
Evaluation of chromosomal abnormalities and common trombophilic mutations in cases with recurrent miscarriage
}

\author{
Ahmet Karatas ${ }^{1}$, Recep Eroz ${ }^{2}$, Mustafa Albayrak ${ }^{3}$, Tulay Ozlu ${ }^{1}$, \\ Bulent Cakmak ${ }^{4}$ Fatih Keskin ${ }^{3}$
}

1. Abant Izzet Baysal University, Izzet Baysal Medical Faculty, Department of Obstetrics and Gynecology, Bolu, Turkey.

2. Duzce University Medical Faculty, Department of Medical Genetics, Duzce, Turkey.

3. Duzce University Medical Faculty, Department of Obstetrics and Gynecology, Duzce, Turkey.

4. Gaziosmanpasha University Medical Faculty, Department of Obstetrics and Gynecology, Tokat, Turkey.

\begin{abstract}
Background: Recurrent miscarriage (RM) is a frequent obstetric problem. Its' pathophysiology is poorly understood. Infections, genetic, endocrine, anatomic and immunologic problems have been suggested as causes for RM.

Objective: To evaluate the frequency of chromosomal abnormalities and 3 common thrombophilic mutations in couples with RM.

Methods: A retrospective data collection was performed for the results of the cytogenetic analysis of the couples and Methylenetetrahydrofolate Reductase (MTHFR) C677T, Factor V Leiden (FVL) G1691A and Prothrombin (PTm) G20210A mutations of the mother in 142 couples suffering from RM.

Results: Prevalence of FVL, MTHFR, and PTm gene mutations were similar between cases shaving 2 or $\geq 3$ abortions $(\mathrm{P}=0.528 ; \mathrm{P}=0.233 ; \mathrm{P}=0.375)$. In patients with $\mathrm{FVL}, \mathrm{MTHFR}$ and $\mathrm{PTm}$ gene mutations, the OR's of having $\geq 3$ abortions when compared to having 2 abortions were 1.515 (95\% CI: 0.414-5.552), 0.573 (95\% CI: 0.228-1.441), and 2.848 (95\% CI: 0.355-22.871). All cases with PTm mutation had $\geq 3$ abortions and all abortions occurred between 6-8 gestational weeks.

Conclusion: Chromosomal abnormalities and thrombophilic mutations (especially PTm) seem to have an important role in RM. Additional larger studies involving investigation of more genes that may have a role in pregnancy are needed to assess this association.
\end{abstract}

Key Words: Recurrent miscarriage, chromosomal abnormalities, inherited thrombophilic polymorphisms African Health Sciences 2014;14(1): 216-222 http://dx.doi.org/10.4314/ahs.v14i1.34

\section{Introduction}

Recurrent miscarriage (RM) is defined as the occurrence of 3 consecutive first trimester pregnancy losses. It affects $1 \%$ of all women (1). The ratio increases from $1 \%$ to $5 \%$, if it is defined as $\geq 2$ losses (2). It is a frustrating condition both for the couple and the clinician. Among women with RM, recurrencerisk appears to be higher in those with prior fetal death in contrast to early first trimester losses (3). Historically, RM has been attributed to chromosomal abnormalities, throm bophilic, endocrinologic, immunologic, microbiologic,

\section{Corresponding Author: \\ Ahmet Karatas \\ Abant Izzet Baysal \\ University Medical Faculty, \\ Department of Obstetrics and \\ Gynecology, 14280, Golkoy, \\ Bolu, Turkey \\ Phone: 009037425346 56, \\ Fax: 00903742534615 \\ E-mail: akaratas1973@hotmail.com}

metabolic, anatomic or iatrogenic factors. Maternal age and obesity at conception have both been shown to be associated with RM $(4,5)$. However, a great proportion of the causes remain un-explained, despite detailed investigation (6).

In approximately $4 \%$ of couples with RM, one of the partners carries either a balanced reciprocal translocation, in which there is an exchange of two terminal segments from different chromosomes, or, a Robertsonian translocation, in which there is a centric fusion of two acrocentric chromosomes $(7,8)$.

Pregnancy is a hypercoaguable state $(9,10)$ and thrombophilic disorders are a diverse group of coagulation disorders associated with a predisposition for thrombotic events. Three common thrombophilic mutations were identified: Factor V Leiden (FVL) G1691A; factor II prothrombin (PTm) G20210A and methylene tetrahydrofolate reductase (MTHFR) C677T. There are conflicting studies in the literature about the role of these thrombophilic mutations in RM, and results of some of thesis were in favor of the possible association between RM and thrombophilic mutations $(11,12)$. 
In this study, we wanted to evaluate the frequency of chromosomal abnormalities and these 3 common thrombophilic mutations in couples with RM.

\section{Methods}

This retrospective study was carried out by the Obstetrics \& Gynecology and Medical Genetics Departments of Duzce University School of Medicine. The study was approved by Non-Invasive Human Research Ethics Committee of Duzce University. 178 couples suffering from RM ( $\geq 2$ pregnancy losses that occurred before the $20^{\text {th }}$ gestational week) and admitted to the obstetrics and gynecology outpatient clinic, between January 2010 and August 2012 were retrospectively evaluated. Demographic characteristics, results of the maternal and paternal chromosomal analysis as well as the results of FVL G1691A; PTm G20210A and MTHFR C677T polymorphisms in the mother were obtained from patients' files. Patients with incomplete records were excluded. Patients were evaluated in two groups as those having 2 abortions and those having $\geq 3$ abortions.

\section{Cytogenetic Analysis}

Metaphase chromosome preparations from the peripheral blood cultures were made according to standard cytogenetic protocols. Cytogenetic analysis was performed by G-bands by trypsin using Giemsa (GTG) banding at approximately 400-450 band level. For each cases, 20 metaphases were analyzed. Chromosomal abnormalities were detected according to the present international standard nomenclature (ISCN).

\section{Isolation of Genomic DNA}

Blood samples were collected in tubes containing ethylene diamine tetra acetic acid (EDTA) for DNA isolation. Genomic DNA was isolated from individuals via fenol-chloroform extraction methods.
Determination of MTHFR C677T, Factor V Leiden G1691 A and Factor II Prothrombin G20210A polymorphisms

Polymerase chain reaction-restriction fragment length polymorphism (PCR-RFLP) by using appropriate primers was used to detect these single nucleotide polymorphisms. MTHFR C677T polymorphism was detected by using the previously described couples of primers and PCR products were digested by Hinf I restriction endonuclease enzyme (13). FVL polymorphism was detected with by using to primers FV1, FV2 and the restriction enzyme Mnl 1(14). PTm was detected by using 2 primers, PT1 and PT2 followed by digestion of the product with the restriction enzyme Hind III (15).

\section{Statistical Analysis}

All analyses were performed using the Statistical Package for Social Sciences (SPSS version 15.0) and the data were given as mean \pm SD and percentages. Pearson $\chi^{2}$ and Mann-Whitney $U$ tests were used. The odds ratios (OR's) with 95\% confidence intervals (CI's) were calculated. The statistical significance level was defined as $\mathrm{P}<0.05$.

\section{Results}

A total of 142 couples were included in the study. Mean age of the women was $30.3 \pm 5.5$ years $(20-44)$, and 32 of them were $\geq 35$ years. Mean age of the men was $33.1 \pm 5.5$ years $(23$ - 46). Parity, abortion and the number of living children were similar in patients < and $\geq 35$ years of age $(p=0.167 ; p=0.358 ; p=0.153$, respectively).

Chromosomal analysis of the couples revealed 128 normal results, 9 polymorphisms, 3 translocations and 2 trisomy $\mathrm{X}$ for women; 123 normal results and 19 polymorphisms for men (Table 1).

Table 1.Chromosom analysis results of women and men with recurrent miscarriage.

\begin{tabular}{|c|c|c|c|}
\hline $\begin{array}{l}\text { Chromosomal analysis results of } \\
\text { women }\end{array}$ & $\mathrm{n}$ & $\begin{array}{l}\text { Chromosomal analysis results of } \\
\text { men }\end{array}$ & $\mathbf{n}$ \\
\hline 46,XX,1qh+ & 5 & 46,XY,1qh+ & 4 \\
\hline 47,XXX & 2 & 46,XYqh- & 2 \\
\hline 46,XX,16qh+ & 3 & 46,XYqh+ & 5 \\
\hline 46,XX,13pstk+ps+ & 1 & 46,XY,15ps+ & 1 \\
\hline 46,XX,t(13;16) (q34,q12) & 3 & 46,XY,9qh+ & 4 \\
\hline \multirow[t]{4}{*}{$46, X X$} & 128 & 46,XYqh+, 9qh+ & 1 \\
\hline & & 46,XY,21pss & 1 \\
\hline & & 46,XY,21 cenh+ & 1 \\
\hline & & $46, X Y$ & 123 \\
\hline Total & 142 & & 142 \\
\hline
\end{tabular}


$95 \%$ of the abortions were in the first trimester and $5 \%$ of them were in the second trimester. When results of the chromosomal analysis were investigated according to the number of abortions; there were 23 normal results and 1 polymorphism in couples with 2 abortions; 84 normal results, 8 polymorphisms, 2 trisomy $\mathrm{X}$ and 2 translocations in couples with 3 abortions and 21 normal results and 1 translocation in couples with $>3$ abortions.
FVL status was normal, showed a heterozygous mutation and showed a homozygous mutation in 118, 19 and 5 of the cases, respectively. MTHFR results were normal in 63 cases, and there was a heterozygous or homozygous mutation in 67 and 12 of the cases, respectively. The analysis for PTm were normal in 128 cases and showed a heterozygous mutation in 14 cases. Distribution of the FVL, MTHFR, and PTm results of women according to the number of abortions were shown in table 2 $(p=0.560 ; p=0.266 ; p=0.558$, respectively).

Table 2.Thrombophilia analysis of women according to abortus number.

\begin{tabular}{|c|c|c|c|c|c|c|}
\hline \multicolumn{6}{|c|}{ Abortus number } & \multirow[t]{2}{*}{$\mathbf{P}$} \\
\hline \multirow{3}{*}{ FVL } & Normal & $118(83 \%)$ & $21(87.5 \%)$ & $80(83.3 \%)$ & $17(77.2 \%)$ & \\
\hline & Heterozygotes & 19 & $3(12.5 \%)$ & $13(13.5 \%)$ & $3(13.6 \%)$ & \multirow[t]{2}{*}{0.560} \\
\hline & Homozygotes & $\begin{array}{l}(13.3 \%) \\
5(3.5 \%)\end{array}$ & - & $3(3.2 \%)$ & $2(9.2 \%)$ & \\
\hline \multirow{3}{*}{ MTHFR } & Normal & 63 & $8(33.3 \%)$ & $47(49 \%)$ & $8(36.4 \%)$ & \multirow{3}{*}{0.266} \\
\hline & Heterozygotes & $(44.4 \%)$ & $14(58.3 \%)$ & $43(44.8 \%)$ & $10(40.1 \%)$ & \\
\hline & Homozygotes & $12^{(47.2 \%}(8.4 \%)$ & $2(8.4 \%)$ & $6(6.2 \%)$ & $4(18.2 \%)$ & \\
\hline \multirow[t]{2}{*}{ PTm } & Normal & 128 & $23(95.8 \%)$ & $85(88.5 \%)$ & $20(90.9 \%)$ & \multirow[b]{2}{*}{0.558} \\
\hline & Heterozygotes & $\begin{array}{l}14(9.1 \%) \\
14.9 \%)\end{array}$ & $1(4.2 \%)$ & $11(11.5 \%)$ & $2(9.1 \%)$ & \\
\hline
\end{tabular}

FVL: Factor V leiden, MTHFR: Methylenetetrahydrofolate Reductase,

PTm:FactorII

Prothrombin

When mutant allels (homozygotes and heterozygotes) were taken into consideration, the prevalence of FVL, MTHFR, and PTm gene mutations were similar between the cases having 2 and $\geq 3$ abortions $(\mathrm{P}=0.528$; $\mathrm{P}=0.233 ; \mathrm{P}=0.375)$. In patients with FVL, MTHFR and
PTm gene mutations, the OR's of having $\geq 3$ abortions when compared to having 2 abortions were 1.515 (95\% CI: $0.414-5.552), 0.573$ (95\% CI: $0.228-1.441)$, and 2.848 (95\% CI: 0.355-2.871) (Table 3).

Table 3. Evaluation of FVL, MTHFR, and PTm gene mutations in cases with 2 and $\geq 3$ abortions.

\begin{tabular}{clccccc}
\hline $\begin{array}{c}\text { Thrombophilic } \\
\text { mutations }\end{array}$ & $\begin{array}{c}\mathbf{2} \text { abortion } \\
\text { (n:24) }\end{array}$ & $\begin{array}{c}\geq 3 \text { abortion } \\
\text { (n:118) }\end{array}$ & $\mathbf{P}$ & OR & 95\% CI \\
\hline FVL & Negative & $21(87.5 \%)$ & $97(82.2 \%)$ & 0.528 & 1.515 & $0.414-5.552$ \\
& Positive & $3(12.5 \%)$ & $21(17.8 \%)$ & & & \\
\multirow{2}{*}{ MTHFR } & Negative & $8(33.3 \%)$ & $55(46.6 \%)$ & 0.233 & 0.573 & $0.228-1.441$ \\
& Positive & $16(66.7 \%)$ & $63(53.4 \%)$ & & & \\
\multirow{2}{*}{ PTm } & Negative & $23(95.8 \%)$ & $105(89 \%)$ & 0.375 & 2.848 & $0.355-2.871$ \\
& Positive & $1(4.2 \%)$ & $13(11 \%)$ & & &
\end{tabular}

FVL: Factor V leiden, MTHFR: Methylenetetrahydrofolate Reductase,

PTm:Factor II Prthrombin

OR: Odds Ratio

CI: Confidence Interval 
The prevalence of combined mutations of FVL $\geq 3$ abortions were similar $(\mathrm{P}=0.634 ; \mathrm{P}=0.189 ; \mathrm{P}=0.259$; + MTHFR, FVL + PTm, MTHFR + PTm and P=0.430, respectively) (Table 4).

combination of 3 mutations in patients with 2 and with

Table4. Evaluation of two and three thrombophilic factor combinations (FVL, MTHFR, and PTm gene) in cases with 2 and $\geq 3$ abortions.

\begin{tabular}{|c|c|c|c|c|c|c|}
\hline \multirow{2}{*}{$\begin{array}{l}\text { Thrombophilic } \\
\text { factors } \\
\text { FVL+ MTHFR }\end{array}$} & & $\begin{array}{c}2 \text { abortion } \\
\text { (n:24) }\end{array}$ & $\begin{array}{c}\geq 3 \text { abortion } \\
(n: 118)\end{array}$ & \multirow{2}{*}{$\begin{array}{c}\mathbf{P} \\
0.634\end{array}$} & \multirow{2}{*}{$\begin{array}{c}\text { OR } \\
0.720\end{array}$} & \multirow{2}{*}{$\begin{array}{c}\mathbf{9 5 \%} \mathbf{0} \mathbf{C I} \\
0.185-2.803\end{array}$} \\
\hline & Negative & $21(87.5 \%)$ & $107(90.7 \%)$ & & & \\
\hline \multirow{3}{*}{ FVL+ PTm } & Positive & $3(12.5 \%)$ & $11(9.3 \%)$ & & & \\
\hline & Negative & $24(100 \%)$ & $110(93.2 \%)$ & 0.189 & - & - \\
\hline & Positive & 0 & $8(6.8 \%)$ & & & \\
\hline \multirow[t]{2}{*}{ MTHFR+PTm } & Negative & $24(100 \%)$ & $112(94.9 \%)$ & 0.259 & - & - \\
\hline & Positive & 0 & $6(5.1 \%)$ & & & \\
\hline \multirow[t]{2}{*}{ Two factor positive } & Negative & $21(87.5 \%)$ & $99(83.9 \%)$ & 0.657 & 1.343 & $0.364-4.957$ \\
\hline & Positive & $3(12.5 \%)$ & $19(16.1 \%)$ & & & \\
\hline \multirow{2}{*}{$\begin{array}{l}\text { Three factors } \\
\text { positive }\end{array}$} & Negative & $24(100 \%)$ & $115(97.5 \%)$ & 0.430 & - & - \\
\hline & Positive & 0 & $3(2.5 \%)$ & & & \\
\hline
\end{tabular}

FVL: Factor V leiden, MTHFR: Methylenetetrahydrofolate Reductase, Prothrombin

OR: Odds Ratio, $\quad$ CI: Confidence Interval

Chromosomal abnormalities and thrombophilic mutations (especially PTm) seem to have an important role in RM.

\section{Discussion}

The rate of karyotypically abnormal abortion specimens increases with maternal age, affected mainly by the increase in the rate of trisomy (16). Chromosomal abnormalities are detected in about one-third of RM's (17). It was reported that normal polymorphic variants contribute to chromosomal instability during meiosis with a tendency towards an increased risk of aneuploidy which can cause RM or sub-fertility (18). Aberrations in the heterochromatin region of the $\mathrm{Y}$ chromosome were identified as the most frequent polymorphism in infertile men (19). The long (Yqh+) and short (Yqh-) chromosome were reported in chromosomal studies of human. (20). While Verp et al. (21) reported Yqh+ to be related with an increased risk of miscarriage, De Braekeleer et al. (20) did not report a relation between Y chromosome size and increased risk of pregnancy loss.

In the present study, there were 14 chromosomal abnormalities in women (8 polymorphism, 3 translocations, 2 trisomy $\mathrm{X}$ in women $<35$ years, and only 1 polymorphism $\geq 35$ years of age). In addition to this, there were 19 polymorphisms in men, and the rest were normal. Five were long (Yqh+) and 2 were short (Yqh-) polymorphisms (Table 1). Therefore Yqh+ and/ or Yqh- may be related with an increased risk of RM.

Thrombophilias make individuals prone to thromboembolism and pregnancy complications including pregnancy loss. Although the mechanism is poorly understood, mutations in genes related with coagulation pathways may cause damage to chorionic vasculature, decreased trophoblast invasion, apoptosis, and impaired uteroplacental circulation due to placental thrombosis. The most common hereditary thrombophilia is the FVL gene mutation followed by the PTm mutation. Both are autosomal dominant conditions (22). In a meta-analysis, Rey et al. (12) had reported FVL mutation to be associated with early and late RM's and with late non-recurrent fetal loss. Some researchers found that there were no significant associations between RM and genetic thrombophilias $(23,24)$, others indicated that there may be a possible relationship between FVL polymorphism and late pregnancy loss (25). In our study, majority of women 
(64.1\%), suffering from RM had at least one of the 3 genetic thrombophilias including FVL, MTHFR or PTm polymorphism.

It was reported that heterozygous carriers for the PTm allele have a 2 to 8 fold increased risk for venous thrombosis (26). Homozygosity for this mutation has been described in very few cases (27). A significant association between PTm carrier-ship and recurrent abortion before 13 weeks of pregnancy was found (12). Similar to the literature findings, in our study, while 128 of cases had normal genotype, the others (14 cases) were heterozygous carriers for the PTm (Table 2). There was no homozygosity for this mutation.

Some researchers indicated that individuals carrying both FVL and PTm mutation have a 20-fold increased risk for venous thrombosis. This rate is higher than for heterozygous carriers of PTm or FVL alone. Thus DNA analysis of both mutations is highly recommended in cases with a personal or family history of thrombosis $(28,29)$. It was reported that a meaningful association between RM and PTm and FVL polymorphisms (12, $22,30)$.

In the current study, there were 8 cases carrying both an FVL and a PTm mutation. All of them were heterozygous for PTm; 7 of them were heterozygous carriers for FVL, while the other case was a homozygous carrier for FVL (only 1 case had 4 abortions, others had 3). Although the differences were not meaningful for PTm and FVL analysis results of women, the abortion rate increased with the positivity for PTm (OR: 2.848 and 95\% CI: 0.355-22.871) and FVL (OR: 1.515 and 95\% CI: 0.414-5.552) as shown in table 3. This insignificant relation may be due to the small sample size.

It was reported that, although the association of pregnancy loss with certain thrombophilic states (such as antiphospholipid antibody syndromes, antithrombin III deficiency) is clear, its association with inherited thrombotic defects such as MTHFR C677T and FVL polymorphisms are slightly disputable (24). In fact, an estimated $10 \%$ of all clinical pregnancies are lost in the first and early second trimester (31), fewer than 3\% of pregnancies are lost later in gestation. The recurrence risk for pregnancy loss appears to be higher in those with previous fetal death in contrast to early first trimester losses in women with RM (3). According to our findings, a great number of abortions (95\%) were observed in first trimester, and $(5 \%)$ in second trimester.

While a lot of studies showed the association of MTHFR C677T polymorphism and increased risk for RM (32-35), some studies reported a lack of relation between this polymorphism and RM $(24,36,37)$. In this study, MTHFR gene mutations were associated with a 0.573 (95\% CI: 0.228-1.441) fold risk of having $\geq 3$ abortions when compared to having 2 abortions (Table 3).

The prevalence of FVL + MTHFR, FVL + PTm, MTHFR + PTm and combination of three mutations were similar in patients with 2 and with $\geq 3$ abortions (Table 4). Interestingly, in the situations which included PTm mutation, all cases $h a d \geq 3$ abortions and all abortions occurred between 6-8th gestational weeks (Table 4). Therefore the presence of PTm gene mutation may be important and may cause early pregnancy losses. Therefore, evaluation of the PTm gene mutation in patients with RM may important.

\section{Conclusion}

Chromosomal abnormalities and abnormalities in the genes related to thrombophilia such as FVL, MTHFR and PTm mutations may be considered as risk factors for RM. Detection of these factors may be important to begin early and appropriate treatment for couples suffering from RM. Thus the physical, psychological discomfort for couples and financial loss for both of couples and governments might be decreased the minimum levels. Additional studies including many genes which have functionally significant variant alleles in pregnancy and a large case series should be performed to obtain more information about this issue.

\section{References}

1. Stirrat GM. Recurrent miscarriage. Lancet 1990;336(8716):673-5.

2. Hogge WA, Byrnes AL, Lanasa MC, Surti U. The clinical use of karyotyping spontaneous abortions. $A m$ J Obstet Gynecol 2003;189(2):397-400.

3. Frias- AE Jr, Luikenaar RA, Sullivan AE, Lee RM, Porter TF, Branch DW, et al. Silver RM. Poor obstetric outcome in subsequent pregnancies in women with prior fetal death. Obstet Gynecol 2004;104(3):521-526.

4. Nybo Andersen AM, Wohlfahrt J, Christens P, Olsen J, Melbye M. Maternal ageand fetal loss: population based register linkage study. BMJ 2000;320(7251):17081712. 
5. Wang JX, Davies MJ, Norman RJ. Obesity increases the risk of spontaneous abortion during infertility treatment. Obes Res 2002;10(6):551-554.

6. Rai R, Regan L. Recurrent miscarriage. Lancet 2006;368(9535):601-611.

7. Stenchever MA, Droegemueller W, Herbst AL, Mishell DR (eds). Spontaneous and recurrent abortion. In: Comprehensive Gynecology (4th edn). St Louis, MO: CV Mosby, 2001;280-299.

8. Clifford K, Rai R, Watson H, Regan L. An informative protocol for the investigation of recurrent miscarriage: preliminary experience of 500 consecutive cases. Hum Reprod 1994;9(7):1328-1332.

9. Stirling Y, Woolf L, North WR, Seghatchian MJ, Meade TW. Haemostasis in normal pregnancy. Thromb Haemost 1984;52(2):176-182.

10. Hellgren M. Hemostasis during pregnancy and puerperium. Haemostasis 1996;26(4):244-247.

11. Kovalevsky G, Gracia CR, Berlin JA, Sammel MD, Barnhart KT. Evaluation of the association between hereditary thrombophilias and recurrent pregnancy loss: a meta-analysis. Arch Intern Med 2004;164(5):558-563.

12. Rey E, Kahn SR, David M, Shrier I. Thrombophilic disorders and fetal loss: a meta-analysis. Lancet 2003;361(9361):901-908.

13. Frosst P, Blom HJ, Milos R, Goyette P, Sheppard CA, Matthews RG, et al. A candidate genetic risk factor for vascular disease: a common mutation in methylenetetrahydrofolate reductase. Nat Genet 1995;10:111-113.

14. Beauchamp NJ, Daly ME, Hampton KK, Cooper PC, Preston FE, Peake IR. High prevalence of a mutation in the factor $\mathrm{V}$ gene within the UK population: relationship to activated protein $\mathrm{C}$ resistance and familial thrombosis. Br J Haematol 1994;88:219-222.

15. Makris M, Preston FE, Beauchamp NJ, Cooper PC, Daly ME, Hampton KK, et al. Co-inheritance of the $20210 \mathrm{~A}$ allele of the prothrombin gene increases the risk of thrombosis in subjects with familial thrombophilia. Thromb Haemost 1997;78:1426-1429.

16. Eiben B, Bartels I, Bähr-Porsch S, Borgmann S, Gatz G, Gellert G, et al. Cytogeneticanalysis of 750 spontaneous abortions with the direct-preparation method of chorionic villi and its implications for studying genetic causes of pregnancy wastage. Am J Hum Genet 1990;47(4):656-663.

17. Hassold T. A cytogenetic study of repeated spontaneous abortions. Am J Hum Genet 1980;32:723-730.

18. Ward KJ. Genetic factors in recurrent pregnancy loss. Semin Reprod Med 2000;18:425-432.

19. Nagvenkar P, Desai K, Hinduja I, Zaveri K. Chro- mosomal studies in infertile men with oligozoospermia \& non-obstructive azoospermia. Indian J Med Res 2005;122(1):34-42.

20. De Braekeleer M, Dao TN. Cytogenetic studies in couples experiencing repeated pregnancy losses. Hum Reprod 1990;5(5):519-528.

21. Verp MS, Rzeszotarski MS, Martin AO, Simpson JL. Relationship between Y-chromosome length and first trimester spontaneous abortions. Am J Obstet Gynecol 1983;145:433-438.

22. Warren JE, Silver RM. Genetics of pregnancy loss. Clin Obstet Gynecol 2008;51(1):84-95.

23. Rai R, Shlebak A, Cohen H, Backos M, Holmes Z, Marriott K, et al. Factor V Leiden and acquired activated protein $\mathrm{C}$ resistance among 1000 women with recurrent miscarriage. Hum Reprod 2001;16(5):961-965.

24. Biswas A, Choudhry P, Mittal A, Meena A, Ranjan $\mathrm{R}$, Choudhry VP, et al. Recurrent abortions in Asian Indians: no role of factor $\mathrm{V}$ Leiden Hong Kong/Cambridge mutation and MTHFR polymorphism. Clin Appl Thromb Hemost 2008;14(1):102-104.

25. Grandone E, Margaglione M, Colaizzo D, d'Addedda M, Cappucci G, Vecchione G, et al. Factor V Leiden is associated with repeated and recurrent unexplained fetal losses. Thromb Haemost 1997;77(5):822-824.

26. Poort SR, Rosendaal FR, Reitsma PH, Bertina RM. A common genetic variation in the 3'-untranslated region of the prothrombin gene is associated with elevated plasma prothrombin levels and an increase in venous thrombosis. Blood 1996;88:3698-3703.

27. Rosendaal FR, Doggen CJ, Zivelin A, Arruda VR, Aiach M, Siscovick DS, et al. Geographic distribution of the $20210 \mathrm{G}$ to A prothrombin variant. Thromb Haemost 1998;79:706-708.

28. McGlennen RC, Key NS. Clinical and laboratory management of the prothrombin G20210A mutation. Arch Pathol Lab Med 2002;126:1319-1325.

29. Press RD, Bauer KA, Kujovich JL, Heit JA. Clinical utility of factor $\mathrm{V}$ leiden (R506Q) testing for the diagnosis and management of thromboembolic disorders. Arch Pathol Lab Med 2002;126:1304-1318.

30. Brenner B, Sarig G, Weiner Z, Younis J, Blumenfeld Z, Lanir N. Thrombophilic polymorphisms are common in women with fetal loss without apparent cause. Thromb Haemost 1999;82:6-9.

31. Miller JF, Williamson E, Glue J, Gordon YB, Grudzinskas JG, Sykes A. Fetal loss after implantation: a prospective study. Lancet 1980;2(8194):554-6.

32. Govindaiah V, Naushad SM, Prabhakara K, Krishna PC, Radha Rama Devi A. Association of parental hy- 
perhomocysteinemia and C677T Methylenetetrahydrofolate reductase (MTHFR) polymorphism with recurrent pregnancy loss. Clin Biochem 2009;42(4-5):380-386. 33. Yenicesu GI, Cetin M, Ozdemir O, Cetin A, Ozen F, Yenicesu C, et al. A prospective case-control study analyzes 12 thrombophilic gene mutations in Turkish couples with recurrent pregnancy loss. Am J Reprod Immunol 2009;63:126-136.

34. Mukhopadhyay R, Saraswathy KN, Ghosh PK. MTHFR C677T and factor $\mathrm{V}$ Leiden in recurrent pregnancy loss: a study among an endogamous group in North India. Genet Test Mol Biomarkers 2009;13:861865.

35. Coulam CB, Wallis D, Weinstein J, DasGupta DS,
Jeyendran RS. Comparison of thrombophilic gene mutations among patients experiencing recurrent miscarriage and deep vein thrombosis. Am J Reprod Immunol 2008;60:426-431.

36. Vettriselvi V, Vijayalakshmi K, Paul SF, Venkatachalam P. ACE and MTHFR gene polymorphisms in unexplained recurrent pregnancy loss. J Obstet Gynaecol Res 2008;34:301-306.

37. Cardona H, Cardona-Maya W, Gomez JG, Castaneda S, Gomez JM, Bedoya G, et al. Relationship between methylenetetrahydrofolate reductase polymorphism and homocysteine levels in women with recurrent pregnancy loss: a nutrigenetic perspective. Nutr Hosp 2008;23:277-282. 